\title{
PENERAPAN SYMBOLIC MODELING MELALUI PENDEKATAN ASUHAN KEPERAWATAN KELUARGA DALAM MENURUNKAN KEJADIAN CEDERA PADA ANAK USIA SEKOLAH
}

\author{
Ressa Andriyani Utami $^{1}$ ) \\ Agus Setiawan ${ }^{2}$ ) \\ Poppy Fitriyani ${ }^{2}$ ) \\ $\left.{ }^{1}\right)$ Akademi Keperawatan RS Husada, Jakarta Pusat, DKI Jakarta 10730,Indonesia \\ $\left.{ }^{2}\right)$ Departemen Keperawatan Komunitas Fakultas Ilmu Keperawatan Universitas \\ Indonesia, Depok 16424, Indonesia \\ E-mail: ressa.andriyani.utami@gmail.com
}

\begin{abstract}
Abstrak
Cedera menjadi ancaman kesehatan dunia karena 7\% kematian diakibatkan oleh cedera. Hasil riset kesehatan dasar (2013) menunjukkan bahwa kejadian cedera yang terjadi di rumah sebanyak 36,5\%. Faktor perilaku yang meliputi pengetahuan, sikap dan keterampilan keluarga terkait pencegahan cedera berpengaruh terhadap kejadian cedera pada anak usia sekolah. Strategi pencegahan cedera yang dilakukan adalah dengan Model Simbol menggunakan video animasi melibatkan keluarga. Penelitian ini bertujuan untuk memberikan gambaran penerapan Model Sandi (Simbol Andi) dalam pencegahan cedera pada keluarga. Desain penelitian ini adalah studi kasus. Jumlah sampel penelitian sebanyak 10 keluarga yang diambil melalui tehnik purposive sampling. Penelitian ini dilakukan selama 6 bulan. Hasil penelitian menunjukkan adanya perubahan pengetahuan, sikap dan keterampilan keluarga serta terjadi peningkatan tingkat kemandirian keluarga. Intervensi Model Sandi diharapkan dapat dijadikan salah satu pendekatan intervensi keperawatan keluarga dalam menyelesaikan permasalahan risiko cedera pada anak usia sekolah.
\end{abstract}

Kata kunci: Model Simbol, intervensi keperawatan keluarga, risiko cedera, anak usia sekolah

\begin{abstract}
Injuries are global health threat because $7 \%$ of deaths are caused by injuries. The results of basic health research (2013) showed that the incidence of injuries that occurred at home as much as 36.5\%. Behavioral factors that include knowledge, attitudes and skills of family and school-age children related to injury prevention affect the incidence of injury in school-aged children. Injury prevention strategy is done with the Symbol Model using video animation involving family. This study aims to provide an overview of the application of Model Sandi (Simbol Andi) in the prevention of injury to the family. The design of this study is a case study. The number of research samples are 10 families taken through purposive sampling technique. This research was conducted for 6 months. The results of the study showed that there was a change of knowledge, attitudes and skill of the family as well as the increasing of family independence level. Intervention Model Sandi is expected to be one of the approaches of family nursing interventions in solving the problem of risk of injury in school-aged children.
\end{abstract}

Keywords: Symbolic modeling, family nursing intervention, risk of injury, school-aged children 


\section{PENDAHULUAN}

Keluarga merupakan sekumpulan orang yang bersatu karena memiliki kedekatan emosional, kebersamaan karena ikatan darah pernikahan maupun proses adopsi (Friedman et al, 2003). Salah satu fungsi keluarga adalah fungsi perawatan kesehatan yang meliputi pemberian perawatan kesehatan yang bersifat preventif (Friedman et.al, 2003). Usaha pencegahan cedera merupakan langkah awal yang harus dilakukan keluarga untuk memitigasi masalah kesehatan yang lebih parah (Darmojo, 2006).

Herdman dan Kamitsuru (2014) mendefinisikan risiko cedera adalah hasil interaksi antara lingkungan dengan respon pertahanan individu. Cedera merupakan kerusakan yang timbul baik fisik maupun mental akibat suatu agen eksternal (Dewi \& Indarwati, 2011). Kuschithawati, et al (2007) menjelaskan bahwa cedera terjadi akibat keingintahuan anak dan keberanian melakukan tindakan diluar kemampuan pada perkembangan motoriknya sehingga menimbulkan bahaya. Kelompok anak usia sekolah merupakan populasi berisiko (at risk population) yaitu sekelompok orang yang terpapar faktor risiko dan memiliki ancaman kesehatan (Stanhope \& Lancaster, 2016).

Cedera yang berpotensi terjadi pada usia ini adalah kecelakaan kendaraan bermotor, tersayat pisau, tenggelam, luka bakar, keracunan, terjatuh. Nugrahatmaja (2011) menjelaskan faktor-faktor yang mempengaruhi terjadinya kecelakaan pada anak dapat dikatagorikan menjadi tiga bagian, yaitu: karakteristik anak (meliputi umur dan tingkat perkembangan, jenis kelamin, kemampuan kognitif, afektif dan motorik serta tingkat aktivitas anak), karakteristik agen penyebab (air, api, mainan, tempat bermain dan bahan beracun), dan karakteristik lingkungan (lingkungan fisik dan sosiokultural). Zolten dan Long (2006) menjelaskan lebih lanjut bahwa faktor lingkungan ini salah satunya adalah lingkungan keluarga, yaitu berupa pola pengasuhan anak dalam keluarga (parenting) dan perhatian keluarga terhadap faktor risiko cedera pada anak.

Dalam proses pelaksanaan program, keterlibatan keluarga sangat dibutuhkan untuk mengawal perubahan perilaku yang diharapkan. Pendekatan keperawatan keluarga dilakukan melalui teori Family Centered Nursing yang meliputi pengkajian dan pendekatan keluarga. Keluarga merupakan unit dasar dalam mengembangkan praktek asuhan keperawatan sebelum menuju unit yang lebih besar yaitu masyarakat dan komunitas. Teori ini mengintegrasikan pelayanan asuhan keperawatan dengan kondisi sosioekonoi, etnik, ras dan budaya yang diadopsi oleh keluarga. (Hitchcock, Schubert \&Thomas, 1999).

Program pemerintah yang ada saat ini yaitu Gerakan Masyarakat Sehat (Germas) melalui pendekatan keluarga sedang diterapkan di Kota Depok. Akan tetapi penerapan terkait pencegahan dan penanganan cedera pada anak usia sekolah belum dilaksanakan secara maksimal. Program Keluarga Sehat dan Program Kota Ramah Anak yang saat ini diterapkan Kota Depok pun belum mencapai indicator terkait pencegahan cedera pada anak usia sekolah (Kemeneg PP \& PA, 2011).

Perawat keluarga dalam prakteknya harus menstimulasi individu, keluarga dan sistem keluarga untuk dapat sehat secara mandiri. Sehingga proses pengkajian, merumuskan diagnosa keperawatan, intervensi, implementasi, dan evaluasi 
keperawatan akan lebih melibatkan keluarga (Friedman, Bowden, \& Jones, 2003). Friedman, Bowden, \& Jones (2003) dalam melakukan asuhan keperawatan keluarga menerapkan langkah-langkah terkait dengan lima langkah dalam proses keperawatan keluarga. Asuhan keperawatan keluarga dimulai dengan pengkajian keperawatan sampai dengan evaluasi keperawatan keluarga. Dalam pengkajian ditekankan pada struktur dan fungsi keluarga secara menyeluruh dan terintegrasi.

Darmojo (2006) menjelaskan peran keluarga dalam penatalaksanaan cedera yang pertama adalah mengidentifikasi faktor risiko misalnya memastikan penerangan rumah (tidak terlalu redup dan tidak menyilaukan), mengganti peralatan rumah yang tidak aman, kamar mandi tidak licin, lantai datar dan tidak licin. Peran kedua adalah mengatasi faktor situasional misalnya memantau aktifitas fisik yang berbahaya, mendampingi saat berenang, mengajarkan cara menyeberang jalan yang aman, mengajarkan penggunaan korek api, pisau, gunting dan alat berbahaya lainnya.

Perawat keluarga dapat menerapkan suatu bentuk inovasi keperawatan Model Sandi (Simbol Andi) sebagai strategi intervensi keperawatan komunitas untuk mencegah cedera pada anak usia sekolah. Model Sandi merupakan salah satu bentuk strategi pencegahan cedera dan mengurangi timbulnya luka atau cedera dengan mengesksplorasi pengetahuan, sikap dan perilaku. Strategi model simbol mendorong individu atau kelompok untuk mengubah perilaku melalui peniruan terhadap model (Bandura, 1986 dalam Nadratushalihah, 2014). Nelson (1995) serta Pery dan Furukawa (dalam Cormier, 1985) berpendapat bahwa symbolic modeling dipergunakan untuk membentuk perilaku melalui proses observasi pada tokoh melalui film, slide, video, skema tertulis atau audio. Penelitian terkait pencegahan cedera pada anak usia sekolah menggunakan model simbol video animasi melalui pendekatan keluarha selama ini belum pernah dilakukan. Penelitian terkait penerapan model simbol untuk meningkatkan personal safety skill pernah dilakukan oleh Nadratushalihah (2014) tetapi tidak melalui pendekatan keperawatan keluarga.

Berdasarkan latar belakang tersebut perlu dilakukan penelitian terkait penerapan strategi Model Sandi (Simbol Andi) sebagai upaya pencegahan cedera pada anak usia sekolah melalui pendekatan keluarga di Kota Depok.

\section{METODE}

Metode penelitian ini menggunakan metode studi kasus dengan tehnik pengambilan sampel menggunakan purposive sampling artinya sampel yang dipilih sesuai kriteria yang diinginkan peneliti (Cresswell, 2013), yaitu dengan mengelola 10 kasus keluarga binaan dengan masalah keperawatan risiko cedera lalu diberikan asuhan keperawatan. Creswell (2013) menjabarkan bahwa studi kasus adalah metode yang penelitian untuk menyelidiki suatu aktivitas, program, proses atau sekelompok individu secara fokus dan mendalam. Intervensi keperawatan dengan menggunakan bentuk inovasi keperawatan utama: metode model simbol (symbolic modeling) melalui video animasi yang dibuat sendiri oleh peneliti dengan tokoh Andi berdurasi 4 menit 52 detik. Tokoh animasi Andi merupakan anak usia sekolah berusia 11 tahun yang menjadi model atau teladan dalam melakukan tindakan-tindakan pencegahan cedera karena kecenderungan anak usia sekolah melihat contoh dari tokoh-tokoh 
dalam film sehingga keteladanan diterapkan melalui penokohan audio visual. Keluarga diberikan intervensi Model Sandi yang terdiri dari: 12 pertemuan edukasi melalui video animasi, 2 pertemuan story telling, 2 pertemuan games, 2 pertemuan roleplay dan 6 pertemuan latihan keseimbangan. Untuk meningkatkan motivasi pada saat edukasi dilakukan brain gym dan permainan konsentrasi sederhana karena anak usia sekolah memerlukan metode yang lebih atraktif pada saat dilakukan edukasi. Intervensi yang dilakukan kepada orang tua juga meliputi edukasi pencegahan cedera, demonstrasi dan resemonstrasi penanganan cedera sederhana, modeling keluarga, pemantauan dan pengawasan terhadap faktor risiko cedera. Metode yang dilakukan kepada keluarga melibatkan peran serta anak usia sekolah. dan kejadian cedera pada anak usia sekolah. Uji kelayakan/ ethical cleareance dilakukan oleh Komite Etik Penelitian Keperawatan Fakultas Ilmu Keperawatan Universitas Indonesia.

\section{HASIL}

Intervensi keperawatan termasuk inovasi Model Sandi pada keluarga dengan anak usia sekolah yang berisiko mengalami cedera dilakukan evaluasi setelah 6 bulan. Hasil analisis dari karakteristik keluarga didapatkan hasil bahwa 7 dari 10 keluarga memiliki tingkat penghasilan < UMR (Rp. 3.046.180,-), 10 dari 10 keluarga memiliki anak dengan riwayat cedera selama 6 bulan terakhir, 6 dari 10 keluarga merupakan keluarga inti, 7 dari 10 keluarga tidak memiliki kotak P3K di rumah, $70 \%$ keluarga memiliki tingkat pendidikan rendah $(\leq \mathrm{SMP}), 5$ dari 10 kepala keluarga bekerja sebagai karyawan swasta.

Hasil evaluasi didapatkan data terjadi perubahan pengetahuan, sikap dan keterampilan. Pengetahuan keluarga meningkat, hal ini ditandai dengan pengetahuan keluarga yang pada pengkajian awal tidak mengetahui mengenai pencegahan cedera (terjatuh, terkilir, tenggelam, terpotong atau teriris, terkena air panas atau benda panas, tertabrak atau terserempet) setelah diberikan intervensi keluarga mengetahui cara pencegahan cedera. Pada awal pengkajian keluarga tidak mengetahui penanganan cedera sederhana di rumah, setelah diberikan intervensi keperawatan mengetahui cara melakukan penanganan sederhana di rumah seperti penanganan luka terbuka, luka gores, luka memar (mengetahui perbedaan penggunaan providine iodin dan rivanol, waktu dan cara pemberiannya), mengetahui penanganan awal apabila terjadi luka bakar adalah dengan mengalirkan air dingin pada area luka.

Peningkatan sikap ditandai dengan adanya kontrol dan perhatian pada saat anak akan bermain di luar rumah, misalnya dengan selalu meminta izin ketika akan bermain di luar rumah dan bermain tidak melebihi batas waktu yang telah ditetapkan oleh keluarga, keluarga mengatur penggunaan alat yang berbahaya seperti kapan anak diperbolehkan menggunakan pisau, cutter, gunting dan korek api.

Peningkatan perilaku ditandai dengan keluarga mampu memodifikasi lingkungan rumah. Hal ini dibuktikan dengan kondisi rumah dan lingkungan rumah yang sudah mulai diperbaiki seperti lantai rumah dan kamar mandi tidak licin, kaca jendela yang pecah diperbaiki, kondisi perabotan rumah teratur dan rapi, alat dan bahan yang berbahaya dan mengandung zat kimia disimpan di lemari yang sulit dijangkau oleh anak, penataan kabel yang mengandung aliran listrik diperbaiki 
sehingga anak terhindar dari setruman listrik, dipencahayaan rumah tidak redup dan tidak menyilaukan, orang tua melakukan kontrol pada anak saat bermain (seperti di daerah rawakalong, kolam renang, jalan raya), got atau saluran air atau kolam dekat rumah ditutup dan diberi tanda waspada, sumur yang ada di dekat rumah atau dalam rumah diberi penutup dan tanda waspada.

Tabel 1

Gambaran tingkat kemandirian keluarga sebelum dan sesudah intervensi bulan Oktober 2016- April 2017 di Kota Depok $(\mathbf{n}=10)$

\begin{tabular}{cccc}
\hline No & Keluarga & \multicolumn{2}{c}{ Kemandirian keluarga } \\
\cline { 3 - 4 } & & Sebelum & Sesudah \\
\hline 1 & Keluarga A & I & IV \\
\hline 2 & Keluarga T & II & III \\
\hline 3 & Keluarga D & I & III \\
\hline 4 & Keluarga S & I & III \\
\hline 5 & Keluarga N & I & IV \\
\hline 6 & Keluarga K & I & III \\
\hline 7 & Keluarga T & II & IV \\
\hline 8 & Keluarga F & I & IV \\
\hline 9 & Keluarga N & I & IV \\
\hline 10 & Keluarga M & I & IV \\
\hline
\end{tabular}

Berdasarkan tabel 1, tingkat kemandirian keluarga sebelum diberikan intervensi: 8 keluarga termasuk tingkat keluarga mandiri I dan 2 keluarga termasuk tingkat keluarga mandiri II. Setelah dilakukan intervensi, semua keluarga mengalami peningkatan kemandirian dimana 6 keluarga termasuk tingkat keluarga mandiri IV dan 4 keluarga tingkat keluarga mandiri III.

\section{PEMBAHASAN}

Upaya yang dilakukan perawat komunitas untuk mengatasi masalah risiko cedera pada masyarakat salah satunya dengan pendekatan keperawatan keluarga. Pelayanan keperawatan keluarga merupakan kompetensi utama perawat spesialis komunitas. Perawat komunitas harus melakukan upaya untuk meningkatkan cakupan, keterjangkauan dan mutu pelayanan kesehatan untuk mendorong terbentuknya upaya kesehatan bersumber daya masyarakat dan keluarga. Pelaksanaan asuhan keperawatan tidak terlepas dari pelaksanaan asuhan keperawatan keluarga, dimana keluarga adalah merupakan subsistem dari suatu komunitas, sehingga kondisi kesehatan keluarga akan berpengaruh terhadap kondisi kesehatan suatu komunitas. Asuhan keperawatan keluarga juga tidak terlepas dari teori dan model keperawatan Family Centered Nursing. Model ini berfokus pada peningkatan kesehatan seluruh anggota keluarga (Friedman, 2010), dimana keluarga merupakan suatu sistem dimana apabila salah satu anggota keluarga memiliki masalah kesehatan maka akan berdampak pada anggota keluarga yang lain (Friedman, 2010). Pencegahan cedera dapat dilakukan melalui pendekatan pola asuh karena proses tersebut berkelanjutan dalam keluarga (Zolten \& Long, 2006).

Peran keluarga sangat penting dalam mencegah terjadinya cedera pada anak usia sekolah. Pola pemberian nutrisi oleh keluarga dan pengetahuan keluarga juga berdampak terhadap kesehatan anak usia sekolah termasuk insidensi cedera (Utami, R.A, Setiawan, A., Fitriyani, P.) Hasil penelitian Idle (2003) menunjukkan bahwa tingginya pengetahuan keluarga mengenai pencegahan cedera mempunyai peluang 36,3 kali lebih besar dalam menekan terjadinya cedera dibandingkan keluarga dengan tingkat pengetahuan yang rendah. Pengetahuan keluarga dapat ditingkatkan melalui pendidikan atau edukasi. Edukasi yang dilakukan secara multilevel (diberikan pada level individu yaitu anak usia sekolah, keluarga dan komunitas) akan meningkatkan indeks pengetahuan, dan sikap siswa sehingga terjadi penurunan angka cedera (Cao, 
et.al, 2015). Perilaku keluarga dalam mencegah terjadinya cedera pada anak dipengaruhi oleh pekerjaan, usia dan pendidikan keluarga (Notoatmojo, 2007). Semakin tinggi pendidikan ibu, maka semakin baik kemampuan ibu dalam mengidentifikasi factor risiko cedera (Atak et al., 2010).

Salah satu bentuk edukasi yang dilakukan dapat menggunakan metode model simbol (Model Sandi). Hasil intervensi tehnik model simbol ini sejalan dengan studi yang dilakukan Nadratushalihah (2014) yang memperlihatkan peningkatan yang signifikan dalam pengembangan personal safety skill anak. Rosenthal (2005) mengungkapkan bahwa model merupakan sarana untuk meningkatkan kognitif dan sosial seseorang dalam meniru model yang dijadikan contoh dalam upaya mengasah keterampilan kognitif dan sosial seseorang untuk perbaikan perilaku.

Upaya-upaya modifikasi lingkungan rumah dan sekitar rumah juga berkontribusi dalam hal pencegahan risiko cedera. Atak , et.al (2010) mengungkapkan bahwa cedera pada anak dapat terjadi akibat benda-benda yang ada di rumah. Sehingga perlu dilakukan modifikasi lingkungan, seperti penataan barang dan perabotan, memastikan lantai rumah dan kamar mandi tidak licin, menandai area berbahaya dengan peringatan tertulis atau memagari area berbahaya untuk tidak didekati atau dilewati. Hasil studi menunjukkan bahwa lingkungan rumah berpengaruh secara signifikan terhadap penurunan insiden cedera (Mulvaney \& Kenndrick, 2004).

Peningkatan pengawasan orang tua terhadap anak-anaknya juga sangat diperlukan untuk menekan insiden cedera, misalnya mengawasi anak saat berenang atau bermain, memastikan penempatan zat-zat berbahaya jauh dari jangkauan anak-anak. Hal ini sejalan dengan pendapat Kusbiantoro (2014) yang mengungkapkan bahwa praktik pencegahan cedera adalah dengan mengurangi insiden kecelakaan pada anak yang diakibatkan rendahnya pengawasan orang tua. Orang tua pada umumnya memiliki pengetahuan yang baik mengenai ancaman bahaya yang dapat terjadi di rumah, akan tetapi upaya yang dilakukan belum maksimal sehingga perlu dilakukan pembekalan pengetahuan tentang pencegahan dan penatalaksanaan cedera di rumah serta keterampilan penanganan cedera (Morrongiello \& Schwebel, 2008).

Hasil evalusi menunjukkan bahwa terjadi peningkatan pengetahuan keluarga dalam melakukan tingkat pencegahan cedera pada anak usia sekolah. Hasil penelitian serupa menujukan bahwa keluarga dengan tingkat pengetahuan yang tinggi memiliki peluang 36,3 kali lebih besar menurunkan kejadian cedera pada anaknya (Idle, 2013). Hasil evaluasi pada tingkat kemandirian keluarga didapatkan hasil bahwa semua keluarga mengalami peningkatan tingkat kemandirian. Ada 1 keluarga yang memiliki tingkat kemandirian III, hal ini dikarenakan adanya diagnosa penyerta lain yang manjadi prioritas utama serta adanya kesibukan keluarga dalam menerima asuhan keperawatan yang dilakukan.

Keterbatasan pada asuhan keperawatan menggunakan Model Sandi ini adalah bahwa tidak semua keluarga yang memiliki media untuk menanyangkan video pencegahan cedera. Sehingga internalisasi terhadap materi pencegahan cedera tidak dapat maksimal. Terdapat 4 keluarga yang dapat mengulang video menggunakan smartphone. 
Aplikasi pencegahan dan penatalaksanaan cedera melalui model simbol (symbolic modeling) ini memberikan hasil yang efektif dalam melaksanakan asuhan keperawatan pada kasus risiko cedera pada anak usia sekolah, dengan mengoptimalkan peran serta keluarga dan masyarakat di dalamnya, tidak hanya berfokus pada individu yang sakit akan tetapi secara komprehensif melihat dari segi individu, keluarga, kelompok dan komunitas. Hasil penerapan aplikasi model simbol (symbolic modeling) ini memberikan pengalaman bahwa untuk memberikan upaya promotif pada anak usia sekolah memerlukan metode yang tidak biasa, tetapi harus melalui pendekatan yang menarik diantaranya dengan menggunakan apliksi video animasi pendidikan, dongeng atau story telling, permainan atau games. Upaya preventif keluarga dalam mencegah cedera pada anak usia sekolah yang dapat terus dilakukan keluarga diantaranya adalah dengan menciptakan lingkungan yang aman dan bebas bahaya serta terus meningkatkan fungsi pengawasan orang tua terhadap anaknya. Sehingga intervensi kedepannya perlu dilakukan upaya yang berkesinambungan oleh keluarga dengan pengawasan perawat perkesmas untuk terus melakukan program dan edukasi kesehatan yang dapat meningkatkan pengetahuan, sikap dan keterampilan keluarga dalam melakukan pencegahan cedera.

\section{KESIMPULAN}

Strategi intervensi keperawatan Model Sandi (Simbol Andi) merupakan salah satu bentuk upaya promosi kesehatan yang dikembangkan dari Nursing Intervention Classification yang aplikasiny dilakukan menggunakan video animasi, dongeng atau story telling, senam otak atau brain gym yang melibatkan peran serta keluarga, dimana keluarga/ orang tua yang menjadi pengajar dan pengingat kepada anaknya. Hasil evaluasi penerapan Model Sandi di keluarga menunjukkan adanya perubahan sikap, pengetahuan dan keterampilan keluarga dalam pencegahan cedera pada anak usia sekolah dan terjadi peningkatan tingkat kemandirian keluarga.

\section{SARAN}

Keluarga dapat mengaplikasikan Model Sandi (Simbol Andi) sebagai intervensi pencegahan cedera pada keluarga dengan anak usia sekolah dengan memberdayakan keluarga khususnya orang tua dalam melaksanakan model intervensi ini. Dibutuhkan kerjasama dari berbagai pihak baik dari anak, keluarga, perawat puskesmas dan tim kesehatan lain dalam mengaplikasikan Model Sandi (Simbol Andi) sebagai intervensi pencegahan cedera pada keluarga dengan anak usia sekolah sehingga kegiatan asuhan keperawatan ini dapat berkelanjutan baik melalui program perkesmas maupun program keluarga sehat.

\section{DAFTAR PUSTAKA}

Alligood, M.R. \& Tomey, A.N. (2006). Nursing Theorist and their work. 6th Edition, ST. Louis: Mosby Elsevier, Inc

Anderson, Elizabeth T \& Mc. Farlane, Judith (2011). Community as a partner: Theory and practice in nursing. 6th edition. Lippincott: Williams \& Wilkins.

Allender, J.A Rector \& Warner (2014). Community health nursing: promoting and protecting the public health, 8th edition. Philadelphia: Lippincott 
Atak, N., karaoglu, L., Korkmaz, Y., Usubutun, S.A (2010). Household survey: Unintentional injury frequency and related factors among children under five in Malatya. The Turkish Journal of Pediatrics.

Azwar, S., (2000). Sikap Manusia Teory dan Pengukurannya. Edisi 11. Pustaka Pelajar. Yogyakarta

Badan Pusat Statistik (2016). Statistik Indonesia 2015. Jakarta: BPS

Bandura, A, (1986). Social foundations of thought and action. Englewood Cliffs, NJ: Prentice Hall.

Cao, Ling, Quan, Hong, Hui \& Hua (2015). Effect of multilevel education intervention model on knowledge and attitudes of accidental injuries in rural children in Zunyi, Southwest China. International Journal of Environmental Research and Public Health. Vol 12. No4.2015.3903-3914p

CDC. (2010). School Health Programs : Improving the health of our nation's youth. New York: At a glance.

CDC. (2014). School Health Index: A self assessment and planning guide. Elementary School version. Atlanta: Centers for Disease Control and Prevention.

Creswell. J.W. (1998). Qualitative Inquiry and Research Design: Choosing Among Five Tradition. Thoundsand Oaks: Sage Publication. Inc

Depkes RI. (2013). Riset kesehatan dasar. Jakarta: Badan Penelitian dan Pengembangan Kesehatan.

Ervin, N.E (2002). Advanced Community Helath Nursing Practice population
Focused care. New Jersey: Prentice Hall.

Friedman, MM., Bowden, V.R.,\& Jones, E.G. (2010). Family nursing: research theory \& practice. New Jersey:Prentice Hall.

Handoko, T.H. (2001). Manajemen Personalia dan Sumber Daya Manusia. Yogjakarta: BPFE

Herdman, T.H \& Kamitsuru, S. (2014). NANDA International nursing diagnosis: definition and classification, 2015-2017. Oxford: Wiley Blackwell.Bulechek, G. M., Butcher, H. K., Dochterman, J. M., \& Wagner, C. M. (2013). Nursing Intervention Classification (NIC) (6th ed.). St. Louis: Elsevier.

Hitchcock, Schubert dan Thomas (2003). Community health nursing: Caring in action, second edition. USA: Thomson Delmar Learning

Hockenberry, M.J \& Wilson, D (2007). Wong's Nursing Care for Infants and Children, 8thed. St Louis: Mosby

Join Consortium for School Health (2012).Injury prevention, Quick scan of activities and resources in canadian schools. Goverments working across the health and education sectors.

Joint Consortium fo School Health. (2012). What is Comprehensive School Health?. Canada.

Jones, Rebecca A.P (2007). Nursing leadership and management: theories, processes, andpractice. Philadelphia: F.A. Davis Company

Kaakinen, J.R, Vivian, G.D, Coehlo, D.P, \& Hanson S.M.H (2010). Family health care nursing. Theory, practice,

JKH/ Volume 2/ Nomor 1/Januari 2018 (ISSN: 2548-1843, EISSN: 2621-8704) 
and research, 4th edition. Philadelphia: Fa. A Davis

Kemeneg PP \& PA (2011). Kabupaten/ Kota Layak Anak; Bahan Advokasi Kebikajan KLA. Kementrian Pemberdayaan dan Perlindungan Anak Republik Indonesia.

Kemenkes RI (2010). Riskesdas. Kementerian Kesehatan.

Kemenkes RI (2011). Pedoman untuk tenaga kesehatan usaha kesehatan sekolah di tingkatsekolah dasar, sekolah menengah dan pondok pesantren. Direktorat Bina KesehatanAnak. Kemenkes RI.Jakarta

Kemenkes RI. (2013). Riset kesehatan dasar 2013. Jakarta: Kemenkes.

Maglaya, A. S. (2009). Nursing Practice in the Community. (5th ed). Philippine: Argonauta Corporation

Nadratushalihah, (2014). Efektivitas Teknik Symbolic Modeling Untuk Mengembangkan Personal Safety Skills Peserta Didik. Universitas Pendidikan Indonesia.

National Center of Injury Prevention and Control (NCIPC) (2012). A National Action Planfor Child Injury Prevention. CDC gov safechild

National Safety Council. (2006) Pencegahan Cedera . Jakarta: EGC.

Nies, M.A \& Mc.Ewen,M (2015). Community/Public Health nursing 6 th edition: Elsevier

Notoatmojo (2012). Ilmu Perilaku Kesehatan. Jakarta: Rineka Cipta

Orton, Kendrick, West \& Tata (2012). Independent Risk factors for injury in Pre School Children: Three population-based nested case control studies using routine primary care data. Plos ONE 7(4): e35193. The University of Hong Kong

Rahardjo, Susilo \& Gudnanto. (2011). Pemahaman Individu Teknik Non Tes. Kudus: Nora Media Enterprise

Rosenthal, T.L (2005). Psychological modeling: Theory and Practice. Mempha State University

Schwarz, et al. (1993). An injury prevention program in an urban African-american community. American Journal of Public Health; Agricultural and Environment Science Database pg.675.

Sreubert \& Carpenter. (1999). Qualitative Research In Nursing. 3rd Edition. Philadelphia: Lippincott Wiliams \& Wilkins

Stanhope, M., \& Lancaster, J. (2016). Public Health Nursing: PopulationCentered Health Care in the Community (8th ed.). Elsevier Science Health Science Division.

The Canadian Injury Prevention Strategy (2005). The built environment, injury prevention and nursing: a summary of the issues. Canadian nurses association.

Utami, R.A., Setiawan, A., Fitriyani, P. (2016). Menurunkan Risiko Cedera pada Anak Usia Sekolah di Kota Depok Melalui Penerapan Model "Simbol Andi". KIAS: Universitas Indonesia.

Utami, R.A., Setiawan, A., Fitriyani, P. (2016). Hubungan Karakteristik dan Pola Asuh Nutrisi Keluarga terhadap Kejadian Stunting pada Balita. Tesis: Universitas Indonesia. 
Wong, L.D, Wilson, Winkelstein, L.M \& Schwartz, P (2008). Buku ajar keperawatan pediatrik. Edisi terjemahan (ed.6).Jakarta: EGC

Zolten,K. \& Long,N. (2006).Injury prevention for infant, tooddlers \& preschoolers. University of Arkansas: departements of pediatric. 
